\title{
WALTHER VON DER VOGELWEIDE
}

\author{
HERAUSGEGEBEN \\ GEORUNET UND ERLÄUTERT
}

voN

K. SIMROCK

BONN

BEI A D OLF MARCUS

1870 



\section{W. WACKERNAGELS}

\section{ANDENKEN}

GEWIDMET 
